Article

\title{
Lake Zeilu Clay Application Induced Changes in Human Skin Hydration, Elasticity, Transepidermal Water Loss and PH in Healthy Individuals
}

\author{
Samanta Marija Misina ${ }^{1, *}$, Rasma Tretjakova ${ }^{2}$, Sergejs Kodors ${ }^{3}$ and Aleksejs Zavorins ${ }^{4}$ (i) \\ 1 Faculty of Medicine, Rīga Stradinš University, 16 Dzirciema iela, LV-1007 Riga, Latvia \\ 2 Chemistry, Biology and Biotechnology Research Center, Institute of Engineering, Faculty of Engineering, \\ Rezekne Academy of Technologies, 115 Atbrīvošanas aleja, LV-4601 Rezekne, Latvia; rasma.tretjakova@rta.lv \\ 3 Information and Communication Technologies Research Center, Institute of Engineering, \\ Faculty of Engineering, Rezekne Academy of Technologies, 115 Atbrīvošanas aleja, \\ LV-4601 Rezekne, Latvia; sergejs.kodors@rta.lv \\ 4 Department of Dermatology and Venereology, Rīga Stradiňš University, 18 Baznīcas iela, LV-1010 Riga, \\ Latvia; aleksejs.zavorins@gmail.com \\ * Correspondence: samanta.misina@gmail.com
}

Received: 21 May 2020; Accepted: 17 June 2020; Published: 29 June 2020

\begin{abstract}
Clay has a great biomedical application potential, however there are just a few instrumental studies and the impact of lake clay on the skin has not yet been studied. The DermaLab skin analysis system (Cortex Technology) was used for hydration, elasticity, transepidermal water loss (TEWL) and pH measurements after lake clay facial applications. Research included short-term tests (measurements 20 and $60 \mathrm{~min}$ after clay application) and long-term tests (application every 4th day for 3 weeks with measurements 20-24 h post-application). Control measurements and application tests to exclude contact allergy were made beforehand. No volunteer $(n=30)$ had positive allergic reaction. The matched-pairs design was applied: the right and left parts of forehead were used for the test and control groups. The Wilcoxon signed-rank test (significance level $p=0.001$ ) was applied for statistical analysis. There were statistically significant $\mathrm{pH}$ changes demonstrated during the short-term measurements. The long-term measurements provided data that clay significantly improves skin hydration and elasticity.
\end{abstract}

Keywords: clay; skin; elasticity; hydration; $\mathrm{pH}$; transepidermal water loss

\section{Introduction}

Currently, healthy lifestyle is gaining popularity as well as consumers demand for natural products including cosmetics is soaring. The use of clay minerals, especially in biomedical applications, is known from ancient times and they are regaining attention in recent years [1].

Latvia is one of the European countries that have the richest clay deposits per resident [2]. Latvian clay deposits have a potential to be used in manufacturing of cosmetic products containing clay [3].

Clay has effectively proven itself in both cosmetology and dermatology [4-11]. Clays have cleansing, moisturizing, soothing, regenerative, anti-inflammatory, sedative, anti-septic and detoxifying effects; they rejuvenate, tone and nourish the skin $[9,10,12-17]$. Clays can eliminate excess grease and toxins from skin, and hence are said to be effective for dermatological diseases such as furunculosis and management of ulcers [12]. They are used to treat various cutaneous conditions such as seborrheic dermatitis, psoriasis, chronic eczemas and acne $[9,18]$. The study of Carretero et al. report that clay minerals can be powerful in cosmetic products, especially for hair care, due to their peculiar properties [12]. An overview about the use of clay in skin and hair care cosmetics is reported, presenting a general 
introduction regarding these minerals and its wide-ranging application potential in the biomedical field, which could be useful for formulating novel solid shampoo formulas [19].

Recent research shows that clay minerals can protect against ultraviolet (UV) light due to their high specific surface area, therefore providing effective coverage of skin surface. Since most of the clays in Latvia are brown, they can be used as pigment in sunscreens or tonal creams. At the same time, the addition of the clay fraction would increase the sun protection factor (SPF) of the product, thereby decreasing the necessary amount of synthetic UV filters to obtain a certain SPF value [20].

Research of Melo Bentonite, a clay from Uruguay has concluded that additional, but not less important, tests such as the assessment of skin hydration capacity of the clay under study should be performed to assess the efficacy of clay in the skin [21].

There are very few instrumental studies of clay effect on human skin and no studies about lake clay whatsoever. Additionally, each deposit of clay has specific microbiological and physico-chemical characteristics, which must be researched before application. The aim of this research is to experimentally evaluate the impact of Lake Zeilu (Latvia) clay on human skin. The objectives of this research are to determine skin elasticity, hydration, transepidermal water loss (TEWL) and $\mathrm{pH}$ before and after lake clay applications in short- and long-term tests using instrumental methods. The results will be useful in the development of natural products and the application of lake clay in cosmetics and medicine.

\section{Materials and Methods}

Lake clay was obtained from one borehole $(7 \mathrm{~m})$ in Lake Zeilu, Latvia. It contains typical clay crystalline phases-illite, kaolinite and rock forming minerals— quartz, dolomite, calcite, plagioclase, albite and enstatite. Specific surface area varies from $20.32 \mathrm{~m}^{2} / \mathrm{g}$. Adsorption capacity of Lake Zeilu clay varies from $45.8 \mathrm{mg} / \mathrm{g}$. Considering its mineralogical and granulometric content, specific surface area and adsorption capacity, Lake Zeilu clay is suitable for use in cosmetics and medical treatment [22].

The odor of Lake Zeilu clay samples is typical for the clays' odor, color-blue-gray and green-gray, moisture- $46.8 \%$ and consistency-plastic, soft and smooth. According to the microbiological analysis performed, the Lake Zeilu clay meets the requirements of 02.07.2013 Cabinet Regulation No 354 "Procedure for Meeting the Significant Requirements for Cosmetics" and European Standard EN ISO 17516:2014 Cosmetics-Microbiology-Microbiological limits. Lake Zeilu clay is suitable for cosmetical use considering its biological and chemical content [23].

The trial was completed from October to December 2019 in Rezekne Academy of Technologies Chemistry, Biology and Biotechnology Research Center Laboratory of environment health and human life quality. Approval of the Ethics Committee of Rīga Stradinš University (Nr. 6-3/5/6 30.05.2019) was acquired. All subjects gave their informed consent for inclusion before they participated in the study.

Thirty volunteers took part in the study-females aged 20-60 years (average age, 35). They were dermatologically healthy, with no allergies, none was taking anti-inflammatory or hormonal medication. Exclusion criteria were:

- Acne vulgaris or local therapy for acne vulgaris in the past 2 months;

- Localized infection, herpes simplex reactivation, impetigo, psoriasis and rosacea;

- Isoretinoine therapy or photodynamic therapy in the past 6 months;

- Fractional or full facial laser ablation, radiofrequency facial treatment, medium or deep chemical peel and acne scar filling in the past 6 months;

- Decompensated diabetes;

- Light chemical peel, microneedling procedure, mesotherapy and biorevitalization in the past 2 months;

- Systemic antibacterial therapy in the past 2 months;

- Pregnancy or lactation. 
DermaLab multiparameter skin analysis system by Cortex Technology (Cortex, Hadsund, Denmark) was used to measure skin parameters. Measurements were made in the standardized environment (temperature $24.5 \pm 0.5{ }^{\circ} \mathrm{C}$ and relative air humidity $32.8 \% \pm 3.7 \%$ ) after a $15 \mathrm{~min}$ acclimatization period. Hydration and $\mathrm{pH}$ were measured 8 consecutive times, while TEWL and elasticity were measured 3 consecutive times. All measurements were performed in a close proximity to each other. Research contained short-term tests $(1 \mathrm{~h})$ and long-term tests ( 3 weeks). Prior control measurements and contact allergy tests were performed. To determine any contact allergic reactions $12 \mathrm{~cm}^{2}(3 \mathrm{~cm} \times 4 \mathrm{~cm})$ of clay was applied on the volar forearm for $20 \mathrm{~min} 3$ days in a row. The applied area was rinsed with distilled water. All volunteers $(n=30)$ tested negative for contact allergy.

In short-term tests skin elasticity (expressed as viscoelasticity (MPa)), hydration $(\mu \mathrm{S})$, TEWL $\left(\mathrm{g} / \mathrm{m}^{2} \mathrm{~h}\right)$ and $\mathrm{pH}$ were first measured before clay application on the left $\left(\mathrm{TO}_{\text {test }}\right)$ and right $\left(\mathrm{TO}_{\text {control }}\right)$ side of the forehead. Right side was the control area with no applications. On the left side $20 \mathrm{~cm}^{2}(4 \mathrm{~cm} \times 5 \mathrm{~cm})$ of the room temperature lake clay (7-8 g) was applied. After 20 min the clay was removed with wet (lukewarm distilled water) single use napkin of non-woven fabric. Skin elasticity, hydration, TEWL and pH levels were measured repeatedly $20 \mathrm{~min}$ (T20 test and T20 control $)$ and $60 \mathrm{~min}\left(\mathrm{~T} 60_{\text {test }}\right.$ and T60 $0_{\text {control }}$ ) after application removal.

In long-term tests $\mathrm{T}_{\text {test }}$ and $\mathrm{T} 0_{\text {control }}$ were control measurements (elasticity, hydration, $\mathrm{TEWL}$ and $\mathrm{pH}$ ), then the clay mask was applied on the left side every 4 days for 3 weeks with measurements 20-24 h after the $2 \mathrm{nd}\left(\mathrm{T} 5_{\text {test }}\right), 4$ th $\left(\mathrm{T} 13_{\text {test }}\right)$ and 6 th $\left(\mathrm{T} 21_{\text {test }}\right)$ application in the test area and the right side control area ( $\mathrm{T} 5_{\text {control }}, \mathrm{T} 13_{\text {control }}$ and $\left.\mathrm{T} 21_{\text {control }}\right)$.

A data mining analysis was performed to detect hidden internal groups, which could have an impact on the statistical analysis of the results. Data mining analysis included the following tools: descriptive statistic, clustering, Spearman correlation and the "68-95-99.7 rule" as well as the manual analysis of survey forms, which included participant answers to questions related to their health and notes on the visual quality of the skin before the experiment. Three persons with atypical features were identified. The following pairs were analyzed: $\mathrm{T} 0_{\text {test }}$ and $\mathrm{T} 60_{\text {test }}$ - to detect short-term impact, $\mathrm{T} 0_{\text {test }}$ and $\mathrm{T} 21_{\text {test }}$-long-term impact of clay, $\mathrm{T} 0_{\text {control }}$ and $\mathrm{T} 60_{\text {control, }}, \mathrm{T} 0_{\text {control }}$ and $\mathrm{T} 21_{\text {control }}$ - to control that skin parameters were not impacted by an external factor and $\mathrm{T}_{\text {test }}$ and $\mathrm{T}_{\text {control }}$-to test that features of the left and right side of forehead did not significantly differ. The box-and-whisker chart of descriptive statistics was applied for data visualization (see Figure 1). In the result, the dataset for the statistical analysis contained 27 paired samples without a normal distribution. Therefore, the Wilcoxon signed-rank test was applied for statistical analysis to test the null hypothesis that "An unprocessed skin and a skin processed by lake clay are similar". R Project and MS Excel were applied for data mining and statistical analysis.

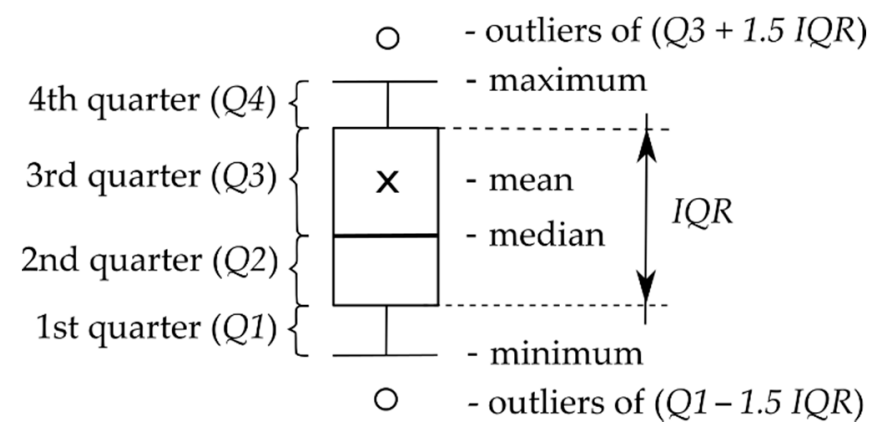

Figure 1. The visual notation of the box-and-whisker chart.

\section{Results}

All volunteers $(n=30)$ had negative contact allergy tests on lake clay. In short-term tests after removal of the clay mask hydration slightly rose from 158.4 ( $\left.\mathrm{T}_{\text {test }}\right)$ to $165.9 \mu \mathrm{S}$ in $\mathrm{T} 20_{\text {test }}$ but dropped to $162.0 \mu \mathrm{S}$ in $\mathrm{T} 60_{\text {test }}$ (Figure 2, Table 1). Furthermore, statistical analysis showed no significant difference 
neither between $\mathrm{T} 0_{\text {test }}$ and $\mathrm{T} 60_{\text {test }}$, nor $\mathrm{T} 60_{\text {control }}$ and $\mathrm{T} 60_{\text {test }}(p>0.001$; Table 2$)$. In the long-term test skin hydration rose from $158 \mu \mathrm{S}$ in the first measurement of $\mathrm{T} 0_{\text {test }}$ to $174.8 \mu \mathrm{S}$ in the last measurement T21 test (Figure 2, Table 1), which was statistically significant difference $(p<0.001)$. The difference between T21 test and T21 control at the end of trials was also statistically significant $(p<0.001$; Table 2$)$.

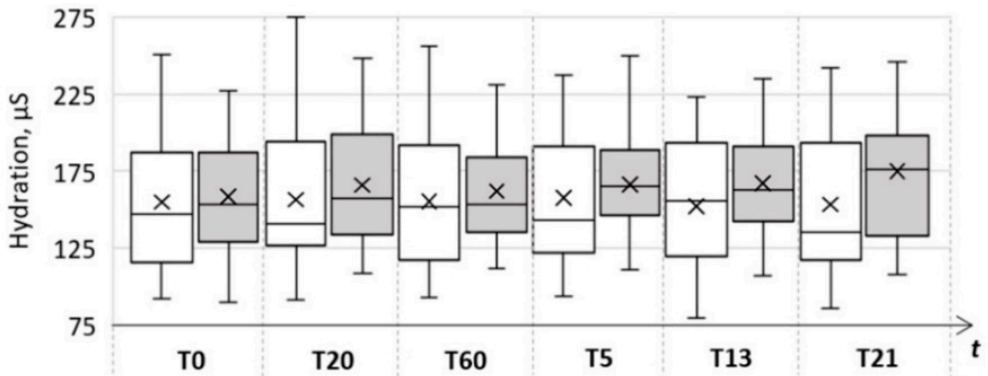

Figure 2. Hydration measurements of the control and test area in the short-term and long-term study (grey boxes are test values, white are control).

Table 1. Mean values and standard deviations of elasticity, hydration, transepidermal water loss (TEWL) and $\mathrm{pH}(n=30)$ in test and control areas.

\begin{tabular}{ccccccc}
\hline Skin Parameter & \multicolumn{3}{c}{ Control Area } & \multicolumn{3}{c}{ Test Area } \\
\hline & T0 & T60 & T21 & T0 & T60 & T21 \\
\hline Elasticity $(\mathrm{MPa})$ & $6.2 \pm 1.0$ & $6.3 \pm 1.1$ & $6.2 \pm 1.2$ & $6.2 \pm 1.2$ & $6.1 \pm 1.2$ & $7.2 \pm 1.5$ \\
Hydration $(\mu \mathrm{S})$ & $154.9 \pm 42.6$ & $155.6 \pm 42.1$ & $153.4 \pm 45.9$ & $158.4 \pm 35.2$ & $162.0 \pm 35.1$ & $174.8 \pm 40.3$ \\
TEWL $\left(\mathrm{g} / \mathrm{m}^{2} \mathrm{~h}\right)$ & $14.7 \pm 5.7$ & $15.7 \pm 6.6$ & $14.6 \pm 4.7$ & $16.3 \pm 8.1$ & $18.5 \pm 11.7$ & $13.6 \pm 6.4$ \\
$\mathrm{pH}$ & $5.2 \pm 0.4$ & $5.4 \pm 0.4$ & $5.3 \pm 0.4$ & $5.2 \pm 0.4$ & $5.5 \pm 0.4$ & $5.3 \pm 0.4$ \\
\hline
\end{tabular}

Table 2. Paired statistical values of elasticity, hydration, TEWL and $\mathrm{pH}(n=30$; statistically significant values in bold).

\begin{tabular}{ccccc}
\hline Pair & Elasticity & Hydration & TEWL & PH \\
\hline $\mathrm{T} 0$ control and $\mathrm{T} 0_{\text {test }}$ & 0.70060 & 0.42080 & 0.17850 & 0.67410 \\
$\mathrm{~T} 0_{\text {control }}$ and $\mathrm{T} 60_{\text {control }}$ & 0.61970 & 0.55560 & 0.04910 & 0.00145 \\
$\mathrm{~T} 0_{\text {control }}$ and $\mathrm{T} 21_{\text {control }}$ & 0.35290 & 0.46130 & 0.85700 & 0.35490 \\
$\mathrm{~T} 0_{\text {test }}$ and $\mathrm{T} 60_{\text {test }}$ & 0.10280 & 0.60240 & 0.06373 & $\mathbf{0 . 0 0 0 0 6}$ \\
$\mathrm{T} 60_{\text {test }}$ and $\mathrm{T} 60_{\text {control }}$ & 0.49250 & 0.15620 & 0.07541 & 0.06600 \\
$\mathrm{~T} 0_{\text {test }}$ and $\mathrm{T} 21_{\text {test }}$ & $\mathbf{0 . 0 0 0 1 5}$ & $\mathbf{0 . 0 0 0 9 6}$ & 0.00325 & 0.02878 \\
$\mathrm{~T} 21_{\text {control }}$ and $\mathrm{T} 21_{\text {test }}$ & $\mathbf{0 . 0 0 0 9 1}$ & $\mathbf{0 . 0 0 0 3 4}$ & 0.03449 & 0.32170 \\
\hline
\end{tabular}

In short-term tests skin elasticity of the test area did not change significantly. Statistical analysis showed no significant difference $(p>0.001)$ between $\mathrm{T} 0_{\text {test }}$ and $\mathrm{T} 60_{\text {test }}$ area and between $\mathrm{T} 60_{\text {test }}$ and

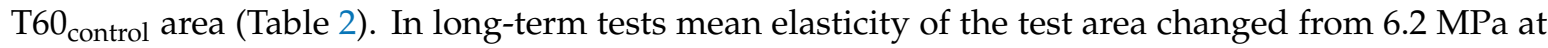
the start ( $\left.\mathrm{T}_{\text {test }}\right)$ to $7.2 \mathrm{MPa}$ in the last test (T21 $1_{\text {test }}$; Figure 3, Table 1). Last measurements $\mathrm{T} 21$ showed a statistically significant difference between the test and control area $(p<0.001)$. The comparison of T0test and T21test area showed a statistically significant difference $(p<0.001$; Table 2).

In short-term tests TEWL increased from T0 test 16.3 to T20 test $19.1 \mathrm{~g} / \mathrm{m}^{2} \mathrm{~h}$ and $\mathrm{T} 60_{\text {test }} 18.5 \mathrm{~g} / \mathrm{m}^{2} \mathrm{~h}$ after mask removal (Figure 4, Table 1), which could be because skin was still slightly wet from the water cloth. On the other hand, in long-term tests there was no statistical significance between both sides, starting the trials $\mathrm{T} 0_{\text {control }}$ and $\mathrm{T} 0_{\text {test }}$, in the end $\mathrm{T} 21_{\text {control }}$ and $\mathrm{T} 21_{\text {test }}$ or between $\mathrm{T} 0_{\text {test }}$ and $\mathrm{T} 21_{\text {test }}$ (Table 2). Even though it was statistically insignificant, TEWL had a tendency to decrease from $\mathrm{T} 0_{\text {test }}$ 16.3 to $\mathrm{T} 21_{\text {test }} 13.6 \mathrm{~g} / \mathrm{m}^{2} \mathrm{~h}$ (Figure 4 , Table 1 ). 


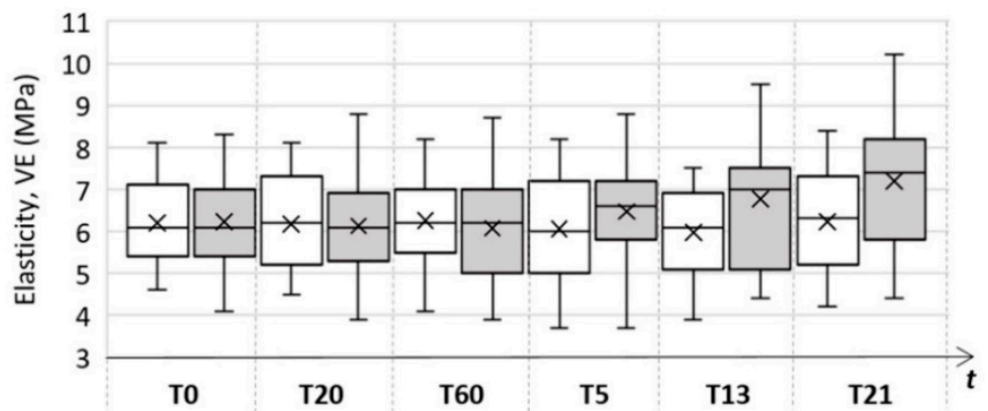

Figure 3. Elasticity measurements of the control and test area in the short-term and long-term study (grey boxes are test values, white are control).

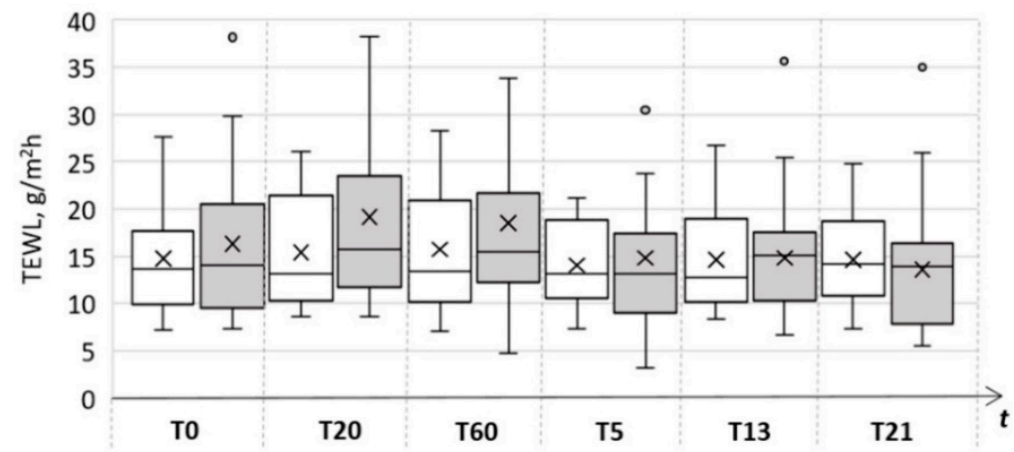

Figure 4. TEWL measurements of the control and test area in the short-term and long-term study (grey boxes are test values, white are control).

In short-term tests $\mathrm{pH}$ rose from 5.2 in $\mathrm{T} 0_{\text {test }}$ to 5.6 (T20 test $)$ and -5.5 in $\mathrm{T} 60_{\text {test }}$ (Figure 5, Table 1). Even though changes were small, the statistical analysis showed a significant difference $p<0.001$. In long-term tests there was no statistically significant $\mathrm{pH}$ differences between $\mathrm{T} 21_{\text {test }}$ and $\mathrm{T} 21_{\text {control }}$ areas and the T0test and T21 test area (Table 2). Therefore, clay use did not significantly change skin $\mathrm{pH}$.

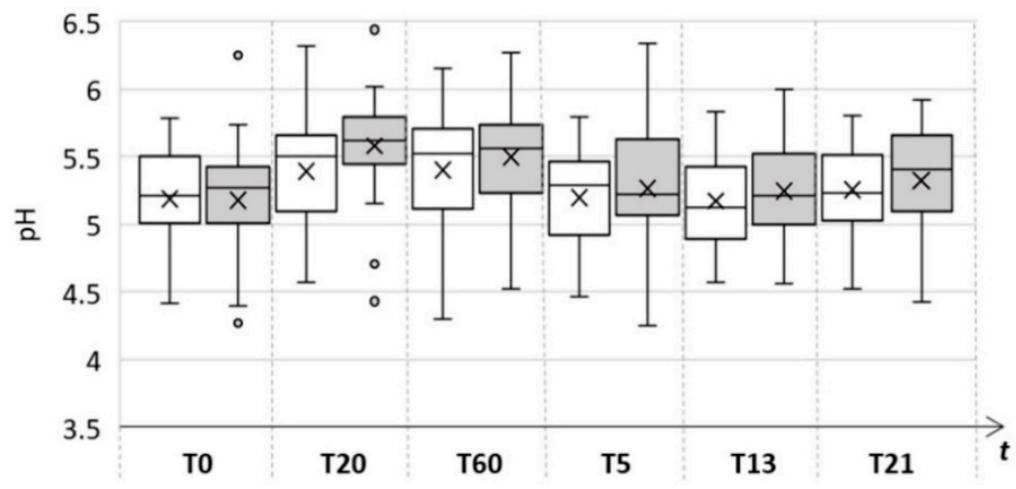

Figure 5. $\mathrm{pH}$ measurements of the control and test area in the short-term and long-term study (grey boxes are test values, white are control).

There were no statistically significant differences between $\mathrm{T}_{0}$ control and $\mathrm{T}_{\text {test }}$ areas in any of the tests. In the control area there was no significant changes in elasticity, hydration, TEWL and pH of the control area. The statistical analysis showed no significant difference between $\mathrm{T} 0_{\text {control, }}, \mathrm{T} 60_{\text {control }}$ and $\mathrm{T} 21_{\text {control }}$ (Table 2). Thus, all changes in skin elasticity, hydration, TEWL and $\mathrm{pH}$ are due to the lake clay use. 


\section{Discussion}

In this research skin hydration increased after long-term tests. That could be explained by the lake clay composition. The $\mathrm{Si}, \mathrm{Al}, \mathrm{Fe}, \mathrm{Mg}, \mathrm{Na}$ and $\mathrm{Ca}$ are the elements constituting the major amount of lake clay [23]. High amounts of Si mean that the clay could be used in the reconstruction of skin tissues, besides providing tissue hydration. Al is relevant in raw materials for cosmetics application since it is well-known for its healing activity, pigment dispersion, hydration and melanin adsorption. Clay can be used as antiseptic and disinfectant, dermatological protector and solar protector $[18,21]$. The granulometric content of lake clay is mostly characterized by silt $(2-63 \mu \mathrm{m})$ and clay $(<2 \mu \mathrm{m})$ fractions [22]. The average particle size of the clay $(26.3 \mu \mathrm{m})$ that is formed by kaolinite, illite and a swelling clay can induce the microcirculation of the skin. Particles smaller than $63 \mu \mathrm{m}$ may have anti-inflammatory effects and assist in the skin hydration, retaining moisture due to the high skin adhesiveness [21,24]. Applied lake clay masks were at room temperature. Moraes notes that warm clay applications cause an increase of perspiration and sebaceous secretion, therefore promoting pore dilation and toxin excretion [25-27]. Heat also opens the pilosebaceous orifices, improving sorption of the cosmetic substances [12]. Thus, it is possible that warm lake clay applications would have had an even better effect.

Lake clay contained crystalline phases-illite and kaolinite [22]. Significant qualities of kaolinites are their opacity, softness and non-abrasiveness [25]. Clay minerals used as dermatological protectors are kaolinite, talc and smectites, which due to their absorbent power, are substances capable of adhering to the skin forming a film, which protects it mechanically against external physical or chemical agents. Paramuds are used to moisturize the skin since during their application the perspiration produced cannot evaporate due to the paramud's impermeability. This perspiration soaks into the upper layers of the epidermis, moisturizing it from within. Moreover, after applying a paramud, the skin is in a hyperporous state, which means that cosmetic substances will be easily absorbed by the corneous layer, reaching the epidermis' deepest layers [9]. That could explain the lake clay effect on skin hydration and gives a thought that the positive effect of clay masks could be even more effective if cosmetic substances were added. The Pan-On et al. study clearly shows that clays play a vital role in the permeation of the active substance through the skin. By selecting the proper clay base, the bioavailability of active substances in clay-based facial mask could be improved [28].

Berardesca et al. state that Amazon white clay forms a film on the skin's surface with a 'patch-like effect' that helps reduce the loss of moisture and retain the main active ingredients, thus enhancing their action [29]. In the current research TEWL demonstrated no statistically significant improvement. As for the technical equipment, Anthonissen et al. 2013 [30] note that DermaLab can be used as an objective, rapid, compact and non-invasive method for elasticity and TEWL analysis in skin yet it is nevertheless necessary to view the results with caution, as the SEMs of both measurements are rather high. In clinical trials they recommend to use a mean of repeated measurements of elasticity and TEWL to decrease the SEM. Saknite et al. 2017 [31] have a similar conclusion: DermaLab measures skin hydration only in the subcutaneous layer (its measurement depth is around $15 \mu \mathrm{m}$ ). Therefore, DermaLab is expected to be more sensitive to even small changes in water content in the stratum corneum. They also noticed an issue regarding measurements by the DermaLab device-for a couple of participants, the skin hydration measurement 1 month later showed an increase of up to 10 times compared to the beginning of the study, which seemed a very unlikely result. The reason might be the use of some specific chemical substances on the skin that systems based on conductance measurements are very sensitive to. In this research during the statistical analysis three persons with atypical features were identified, yet no particular reason was found. It is possible that changes were linked to the hormonal level as these volunteers had hormonal disorders. We repeated each measurement three times but considering previous statements more repeats could be needed.

According to Lynde 2001 [32], traditionally, moisturization was believed to inhibit transepidermal water loss by occlusion. Water originates in the deeper epidermal layers and moves upward to hydrate cells in the stratum corneum, eventually being lost to evaporation. Occlusive moisturization, 
then, prevents the dehydration of the stratum corneum. Considering that this research showed statistically significant hydration improvement and TEWL changes in long-term tests were statistically insignificant yet had a tendency to decrease, it is possible that if tests were run for a longer period of time, the difference could be statistically significant. In the short-term, however, TEWL increased, which was also observed by Kim 2001 [33] —in his study TEWL increased immediately and normalized 4-6 h later after removal of vapor permeable membrane of mud and glycolic acid in both the mouse and human.

Similarly to short-term test observations of this research, Velasco et al. 2016 had concluded that the composition of different clays did not influence skin viscoelasticity behavior in short-term $(20 \mathrm{~min}, 1 \mathrm{~h}$ and $2 \mathrm{~h}$ after mask removal) clinical research [34]. Another study, conducted by Valenti et al., 2011, [35] found that topical kaolinite clay application for 7 days promotes an increase in collagen fibers in rat skin. Seven days after clay treatment, an increase in the number of collagen fibers was observed in treated rat skin compared with control rat skin. Dário et al., 2014, [24] had similar conclusions-after the stability test of clay the wound-healing capacity of the formulation in rats was evaluated. It was observed that the treatment made with the formulation containing the Ocara clay formed by kaolinite and illite showed the best results-greater formation of collagen fibers and regeneration of the deep dermis after seven days of treatment and reepithelialization and continuous formation of granulation tissue on the 14th day. It could be that lake clays have a similar effect on human skin as they improved elasticity in the long-term tests.

The role of the $\mathrm{pH}$ has historically been attributed to antimicrobial defense; however, the latest study points to the regulation of the skin barrier function, epidermal differentiation and desquamation [36]. It is possible to get a general idea of skin $\mathrm{pH}$ through careful observation. Skin that has a soft texture without dry spots would be considered balanced. Irritation, acne, redness and dry spots may all be signs of a high skin $\mathrm{pH}$ [37]. Saba et al. states that skin $\mathrm{pH}$ is normally acidic, ranging in $\mathrm{pH}$ values of 4-6 [38]. Proksch also notes that physiological pH of the stratum corneum is 4.1-5.8 and several mechanisms contribute to its formation: filaggrin degradation, fatty acid content, sodium-hydrogen exchanger activation and melanosome release [36]. This ensures the skin's barrier function is active and guarding against toxins, bacteria and other external factors [39]. Lake clay pH is 5.9-7.3. Smectites show a $\mathrm{pH}$ value comprised of the 8.34-9.75 interval [40]. In comparison, the $\mathrm{pH}$ value of Tunisian clay is 9.7 and this $\mathrm{pH}$ value is appropriate for topical uses of the studied material [41]. Velasco et al. 2016 has researched that the $\mathrm{pH}$ of different clays is 6.5-8.7 [34]. The irritancy potential of cleansing agents is dependent on several factors, which include $\mathrm{pH}$. Even minor differences in the $\mathrm{pH}$ of skin cleansing preparations can be important to the integrity of the skin surface [42]. Therefore, it was important to determine if lake clays change skin $\mathrm{pH}$. $\mathrm{T} 60_{\text {test }}$ showed statistically significant changes, but T21 test $24 \mathrm{~h}$ after mask removal showed no significant difference. Modabberi et al., 2015, Korting et al. 1987 and Moldovan and Nanu 2010 also state that the $\mathrm{pH}$ of the skin surface in the facial region (5.5-6.5) depends on external and internal factors and normal $\mathrm{pH}$ values may increase or decrease after applying topical products, returning to baseline in a few minutes $[40,43,44]$.

\section{Conclusions}

In short-term tests (60 $\mathrm{min}$ ) lake clay applications did not show a statistically significant impact on skin elasticity, hydration, TEWL ( $p>0.001)$, but $\mathrm{pH}$ changes were statistically significant $(p<0.001)$. In long-term tests (3 weeks) lake clay applications showed a statistically significant $(p<0.001)$ impact on skin elasticity and hydration with no significant changes in skin $\mathrm{pH}$. Even though statistically insignificant, TEWL had a tendency to decrease.

Author Contributions: Conceptualization, R.T., S.M.M.; methodology, R.T., S.M.M., A.Z.; software, S.K.; validation, S.M.M., R.T. and S.K.; formal analysis, S.M.M., R.T., S.K.; investigation, S.M.M., R.T.; resources, R.T.; data curation, R.T., S.M.M.; writing_original draft preparation, S.M.M., R.T.; writing—review and editing, R.T., S.M.M., A.Z., S.K.; visualization, R.T., S.K., S.M.M.; supervision, R.T.; project administration, R.T.; funding acquisition, R.T. All authors have read and agreed to the published version of the manuscript. 
Funding: This research was funded by European Regional Development Fund, grant number 1.1.1.2/16/I/001. The APC was funded by Postdoctoral research aid No.1.1.1.2/16/I/001 research application "Identification of blue clay in lakes of Latgale region and possibilities of its application, No.1.1.1.2/VIAA/1/16/131".

Conflicts of Interest: The authors declare no conflict of interest. The funders had no role in the design of the study; in the collection, analysis or interpretation of data; in the writing of the manuscript, or in the decision to publish the results.

\section{References}

1. Massaro, M.; Colletti, C.G.; Lazzara, G.; Riela, S. The use of some clay minerals as natural resources for drug carrier applications. J. Funct. Biomater. 2018, 9, 58. [CrossRef]

2. Forest and Earth Entrails Resources. Available online: https://agris.fao.org/agris-search/search.do? recordID= LV2019000458 (assessed on 19 June 2020).

3. Vecstaudža, J.; Stunda-Zujeva, A.; Irbe, Z.; Bērzin, and suitability of latvian clay for cosmetic purposes. Mater. Sci. Appl. Chem. 2012, 26, 42-48.

4. Haydel, S.; Remenih, C.; Williams, L. Broad-spectrum in vitro antibacterial activities of clay minerals against antibiotic-susceptible and antibiotic-resistant bacterial pathogens. J. Antimicrob. Chemother. 2008, 61,353-361. [CrossRef]

5. Ghiaci, M.; Aghaei, H.; Soleimanian, S.; Sedaghat, S. Enzyme immobilization: Part 1. Modified bentonite as a new and efficient support for immobilization of candida rugosa lipase. Appl. Clay Sci. 2009, 43, 289-295. [CrossRef]

6. Ferrell, R.E. Medicinal clay and spiritual healing. Clays Clay Min. 2008, 56, 751-760. [CrossRef]

7. Williams, L.B.; Haydel, S.E. Evaluation of the medicinal use of clay minerals as antibacterial agents. Int. Geol. Rev. 2010, 52, 745-770. [CrossRef]

8. Carretero, M.I.; Lagaly, G. Clays and health: An introduction. Appl. Clay Sci. 2007, 36, 1-3.

9. Carretero, M.I. Clay minerals and their beneficial effects upon human health. A review. Appl. Clay Sci. 2002, 21, 155-163. [CrossRef]

10. Gomes, C.S.F.; Silva, J.B.P. Minerals and clay minerals in medical geology. Appl. Clay Sci. 2007, 36, 4-21. [CrossRef]

11. Williams, L.B.; Haydel, S.E.; Giese, R.F.; Eberl, D.D. Chemical and mineralogical characteristics of french green clays used for healing. Clays and Clay Miner. 2008, 56, 437-452. [CrossRef]

12. Carretero, M.I.; Gomes, C.S.F.; Tateo, F. 5 clays and human health. Dev. Clay Sci. 2006, 1, 717-741.

13. Meier, L.; Stange, R.; Michalsen, A.; Uehleke, B. Clay jojoba oil facial mask for lesioned skin and mild acne-results of a prospective, Observational Pilot Study. Complementary Med. Res. 2012, 19, 75-79. [CrossRef]

14. Mpuchane, S.F.; Ekosse, G.I.E.; Gashe, B.A.; Morobe, I.; Coetzee, S.H. Microbiological characterisation of southern African medicinal and cosmetic clays. Int. J. Environ. Health Res. 2010, 20, 27-41. [CrossRef]

15. Viseras, C.; Aguzzi, C.; Cerezo, P.; Lopez-Galindo, A. Uses of clay minerals in semisolid health care and therapeutic products. Appl. Clay Sci. 2007, 36, 37-50. [CrossRef]

16. Williams, L.B. Geomimicry: Harnessing the antibacterial action of clays. Clay Miner. 2017, 52, 1-24. [CrossRef]

17. Morrison, K.D.; Misra, R.; Williams, L.B. Unearthing the antibacterial mechanism of medicinal clay: A geochemical approach to combating antibiotic resistance. Sci. Rep. 2016, 6, 19043. [CrossRef]

18. Carretero, M.I.; Pozo, M. Clay and non-clay minerals in the pharmaceutical and cosmetic industries Part II. Active ingredients. Appl. Clay Sci. 2010, 47, 171-181. [CrossRef]

19. Gubitosa, J.; Rizzi, V.; Fini, P.; Cosma, P. Hair care cosmetics: From traditional shampoo to solid clay and herbal shampoo, a review. Cosmetics 2019, 6, 13. [CrossRef]

20. Dušenkova, I.; Kusina, I.; Mālers, J.; Bērziña-Cimdina, L. Application of latvian illite clays in cosmetic products with sun protection ability. In Proceedings of the 10th International Scientific and Practical Conference “Environment. Technologies. Resources”, Rezekne, Latvia, 18-20 June 2015; Rezekne Academy of Technologies: Rezekne, Latvia, 2015.

21. da Silva Favero, J.; dos Santos, V.; Weiss-Angeli, V.; Gomes, L.B.; Veras, D.G.; Dani, N.; Mexias, A.S.; Bergmann, C.P. Evaluation and characterization of Melo Bentonite clay for cosmetic applications. Appl. Clay Sci. 2019, 175, 40-46. [CrossRef]

22. Tretjakova, R.; Noviks, G.; Mezinskis, G. Investigation of structure and composition of clay in lakes of Latgale for practical use. In Proceedings of the 12th International Scientific and Practical Conference “Environment. Technologies. Resources", Rezekne, Latvia, 18-20 June 2019; Rezekne Academy of Technologies: Rezekne, Latvia, 2019; pp. 298-303. 
23. Evaluation and Characterization of Melo Bentonite Clay for Cosmetic Applications. Available online: https://www.researchgate.net/publication/332379849_Evaluation_and_characterization_of_Melo_ Bentonite_clay_for_cosmetic_applications (assessed on 19 June 2020).

24. Dário, G.M.; Da Silva, G.G.; Gonçalves, D.L.; Silveira, P.; Junior, A.T.; Angioletto, E.; Bernardin, A.M. Evaluation of the healing activity of therapeutic clay in rat skin wounds. Mater. Sci. Eng. C 2014, 43, 109-116. [CrossRef]

25. Moraes, J.D.D.; Bertolinob, S.R.A.; Cuffini, S.L.; Ducart, D.F.; Bretzke, P.E.; Leonardi, G.R. Clay minerals: Properties and applications to dermocosmetic products and perspectives of natural raw materials for therapeutic purposes-A review. Int. J. Pharm. 2017, 534, 213-219. [CrossRef]

26. Carretero, M.I.; Pozo, M. Clay and non-clay minerals in the pharmaceutical industry: Part I. Excipients and medical applications. Appl. Clay Sci. 2009, 46, 73-80. [CrossRef]

27. Clijsen, R.; Taeymans, J.; Duquet, W.; Barel, A.; Clarys, P. Changes of skin characteristics during and after local Parafango therapy as used in physiotherapy. Ski. Res. Technol. 2008, 14, 237-242. [CrossRef]

28. Pan-on, S.; Rujivipat, S.; Ounaroon, A.; Kongkaew, C.; Tiyaboonchai, W. Development, characterization and skin irritation of mangosteen peel extract solid dispersion containing clay facial mask. Int. Appl. Pharm. 2018, 10, 202-208. [CrossRef]

29. Berardesca, E.; Abril, E.; Rona, C.; Vesnaver, R.; Cenni, A.; Oliva, M. An effective night slimming topical treatment. Int. J. Cosmet. Sci. 2012, 34, 263-272. [CrossRef]

30. Anthonissen, M.; Daly, D.; Fieuws, S.; Massagé, P.; Van Brussel, M.; Vranckx, J.; Van den Kerckhove, E. Measurement of elasticity and transepidermal water loss rate of burn scars with the dermalab. Burns 2013, 39, 420-428. [CrossRef]

31. Saknite, I.; Zavorins, A.; Zablocka, I.; Kisis, J.; Spigulis, J. Comparison of a near-infrared reflectance spectroscopy system and skin conductance measurements for in vivo estimation of skin hydration: A clinical study. J. Biomed. Photonics Eng. 2017, 3, 1-6. [CrossRef]

32. What They Are and How They Work. Available online: https://www.skintherapyletter.com/eczema/howmoisturizers-work/ (accessed on 10 May 2020).

33. Kim, S.; Hwang, S.M.; Choi, E.H.; Ahn, S.K.; Lee, S.H. The effect of bentonite and glycolic acid on the stratum conium. Ann Derm. 2001, 13, 205-210. [CrossRef]

34. Maria, V.; Zague, V.; Dario, M.; Nishikawa, D.; Pinto, C.; Almeida, M.; Trossini, G.; Vieira-Coelho, A.; Baby, A. Characterization and short-term clinical study of clay facial mask. J. Basic Appl. Pharm. Sci. 2016, 37, 1-6.

35. Valenti, D.M.Z.; Silva, J.; Teodoro, W.R.; Velosa, A.P.; Mello, S.B.V. Effect of topical clay application on the synthesis of collagen in skin: An experimental study. Clin. Exp. Dermatol. 2012, 37, 164-168. [CrossRef]

36. Proksch, E. PH in nature, humans and skin. J. Derm. 2018, 45, 1044-1052. [CrossRef] [PubMed]

37. About Skin PH and Why it Matters. Available online: www.healthline.com/health/whats-so-importantabout-skin-ph (accessed on 10 May 2020).

38. Ali, S.M.; Yosipovitch, G. Skin pH: From basic science to basic skin care. Acta Derm. Venereol. 2013, 93, 261-267. [CrossRef] [PubMed]

39. What is Skin's PH Level and How to Maintain it? Available online: www.stylecraze.com/articles/whatis-the-importance-of-ph-on-your-skin-and-what-you-can-do-about-it/\#WhatIsSkinpHLevel (accessed on 10 May 2020).

40. Modabberi, S.; Namayandeh, A.; López-Galindo, A.; Viseras, C.; Setti, M.; Ranjbaran, M. Characterization of Iranian bentonites to be used as pharmaceutical materials. Appl. Clay Sci. 2015, 116, 193-201. [CrossRef]

41. Gamoudi, S.; Srasra, E. Characterization of Tunisian clay suitable for pharmaceutical and cosmetic applications. Appl. Clay Sci. 2017, 146, 162-166. [CrossRef]

42. Yosipovitch, G.; Hu, J. The importance of skin pH. Ski. Aging 2003, 11, 88-93.

43. Korting, H.C.; Kober, M.; Mueller, M.; Braun-Falco, O. Influence of repeated washings with soap and synthetic detergents on $\mathrm{pH}$ and resident flora of the skin of forehead and forearm. Acta Derm. Venereol. 1987, $67,41-47$.

44. Moldovan, M.; Nanu, A. Influence of cleansing product type on several skin parameters after single use. Farmacia 2010, 58, 29-37.

(C) 2020 by the authors. Licensee MDPI, Basel, Switzerland. This article is an open access article distributed under the terms and conditions of the Creative Commons Attribution (CC BY) license (http://creativecommons.org/licenses/by/4.0/). 